Review Article

\title{
Fabrication techniques involved in developing the composite scaffolds PCL/HA nanoparticles for bone tissue engineering applications
}

\author{
Sivasankar Murugan ${ }^{1} \cdot$ Sreenivasa Rao Parcha ${ }^{1}$
}

Received: 21 September 2020 / Accepted: 28 May 2021 / Published online: 11 August 2021

(c) The Author(s) 2021

\begin{abstract}
A fine-tuned combination of scaffolds, biomolecules, and mesenchymal stem cells (MSCs) is used in tissue engineering to restore the function of injured bone tissue and overcome the complications associated with its regeneration. For two decades, biomaterials have attracted much interest in mimicking the native extracellular matrix of bone tissue. To this aim, several approaches based on biomaterials combined with MSCs have been amply investigated. Recently, hydroxyapatite (HA) nanoparticles have been incorporated with polycaprolactone (PCL) matrix as a suitable substitute for bone tissue engineering applications. This review article aims at providing a brief overview on PCL/HA composite scaffold fabrication techniques such as sol-gel, rapid prototyping, electro-spinning, particulate leaching, thermally induced phase separation, and freezedrying, as suitable approaches for tailoring morphological, mechanical, and biodegradability properties of the scaffolds for bone tissues. Among these methods, the 3D plotting method shows improvements in pore architecture (pore size of $\geq 600 \mu \mathrm{m}$ and porosity of $92 \%$ ), mechanical properties (higher than $18.38 \mathrm{MPa}$ ), biodegradability, and good bioactivity in bone tissue regeneration.
\end{abstract}

\section{Graphical Abstract}

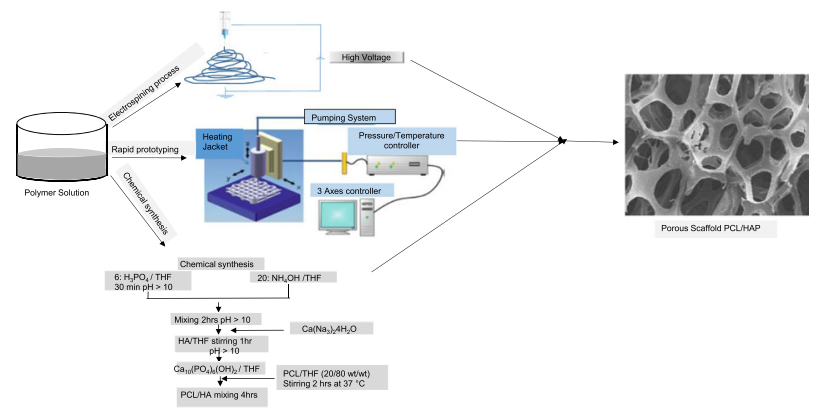

Sreenivasa Rao Parcha

parcha@nitw.ac.in

1 Stem Cell Research Laboratory, Department of Biotechnology, National Institute of Technology, Warangal, Telangana 506004, India

\section{Introduction}

Bone is a rigid, complex, and hierarchical structure consisting of collagen and hydroxyapatite (HA), which provides hardness and toughness to the tissue. Bone tissue consists of two different structures: an outer cortical bone, with less than $10 \%$ porosity, and an inner cancellous bone, with a porosity of 50-90\%. Both structures undergo dynamic remodeling, maturation, differentiation, and resorption that are controlled via interactions among osteocyte, osteoblast, and osteoclast cells [1]. In bone remodeling, osteoblasts are primarily responsible for a new bone formation, while osteoclasts are responsible for bone 
Fig. 1 Scheme of composite scaffold by solvent casting and particulate leaching fabrication method

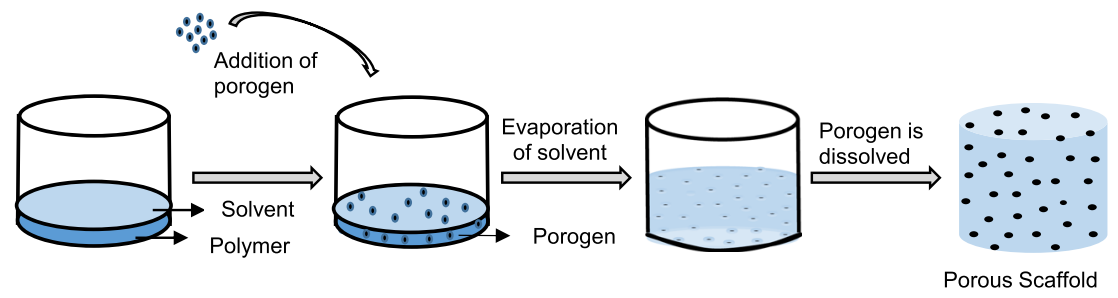

resorption which is a dynamic process for maintaining a healthy bone [2]. Bone-related defects can be caused by many conditions, including trauma, tumors, and bone diseases, which cannot heal by themselves. Tissue engineering emerges as a potential approach to overcome the challenges of conventional in bone graft treatments [3]. Bone tissue engineering strategies involve a combination of scaffolds, growth factors, and stem cells to restore the function of injured tissue and overcome the complications associated with bone and other tissues repairing [4-8]. The scaffold should meet specific characteristics, such as physicochemical and mechanical properties, to achieve cell attachment, proliferation, and maturation, thereby enabling bone tissue formation [9-12]. The interconnected porous structure and pore size distribution are important factors to be considered for 3D scaffold fabrication, which contributes to cell penetration into the scaffold, and allowing an adequate colonization of the scaffold. A pore size with the high surface to volume ratio, as well as porosities, support cell attachment, proliferation, and osteodifferentiation by mimicking the extracellular matrix (ECM) of natural bone tissue [13-15]. Scaffolds with pores diameter of 100-300 $\mu \mathrm{m}$ enable successful diffusion of essential nutrients and oxygen for cell survival, and efficiently regulate the differentiation of stem cells [16-19]. Mesenchymal stem cells (MSCs) can differentiate into numerous categories of cells, which include adipocytes, osteocytes, fibroblasts, and chondrocytes. MSCs have been widely studied compared to other stem cell types for the development of engineered tissue/cell-based therapies [20, 21]. The adipose tissue is the richest source of MSCs in adults, easily accessible [22]. Adipose tissue-derived MSCs lack of phenotypic characterization but they are marked by a low immunogenicity [23]. These cells are designed at the molecular level with immunophenotype properties [17]. Whereas the choice of a proper biomaterial for a three-dimensional scaffold fabrication is crucial in stimulating bone regeneration [24, 25]. Scaffolds are designed to avoid immunological rejection and make them biocompatible, biodegradable, and regulate cell proliferation and differentiation, by controlling their physico-chemical properties [26, 27]. Natural and synthetic polymers have been widely used as biomaterials due to their unique properties such as porosity, pore size, biokinetics, physicochemical, and mechanical properties. HA is widely used as promising osteogenic biomaterial, due to its chemical and structural similarity with mineral phase of bone ECM, along with slow biosorption [28]. Among synthetic polymers, poly-caprolactone (PCL) is a semi-crystalline polyester widely used as biomaterials in medical applications. PCL has a low melting point $\left(55^{\circ} \mathrm{C}\right)$ and suitable properties (porosity, degradation time, and bioreabsorption) for bone tissue regeneration. PCL has a poor wetting surface and establishes weak interactions with biological fluids, preventing cell adhesion and proliferation. For this reason, HA has been incorporated in PCL matrix enhancing mechanical properties and osteogenic features of final PCL/ HA scaffolds [29, 30]. This review article aims at providing a brief overview on PCL/HA composite scaffold fabrication techniques such as sol-gel, rapid prototyping, electrospinning, particulate leaching, thermally induced phase separation (TIPS), and freeze-drying, as suitable approaches for tailoring morphological, mechanical, and biodegradability properties of the scaffolds for bone tissues, but cannot be completely controlled through these methods. Among these methods, the 3D plotting method shows improvements in pore architecture, mechanical properties, biodegradability, and good bioactivity in bone tissue regeneration.

\section{Methods involved in the fabrication of 3D scaffolds}

\subsection{Solvent casting and particulate leaching}

Particulate leaching method, involving a polymer solution incorporated with salt particles of a known diameter, still attracts great interest with the aim of developing optimal porogen with paraffin beads [31], sucrose, and sodium bicarbonate as ingredients [32]. Salt, sugar, glucose, gelatin, and ammonium chloride are used to produce the pores [33-40]. Microporous structure with the pore size of $300-350 \mu \mathrm{m}$ is formed, after soaking the scaffolds in water, where the porogen $(250 \mu \mathrm{m})$ dissolves completely leaving behind the empty spots corresponding to pores (Fig. 1) [41]. Fabbri et al., reported a combination of sodium chloride and sodium bicarbonate as porogen, to develop a PCL/HA composite scaffold showing a $70-80 \%$ porosity, good interconnectivity, 


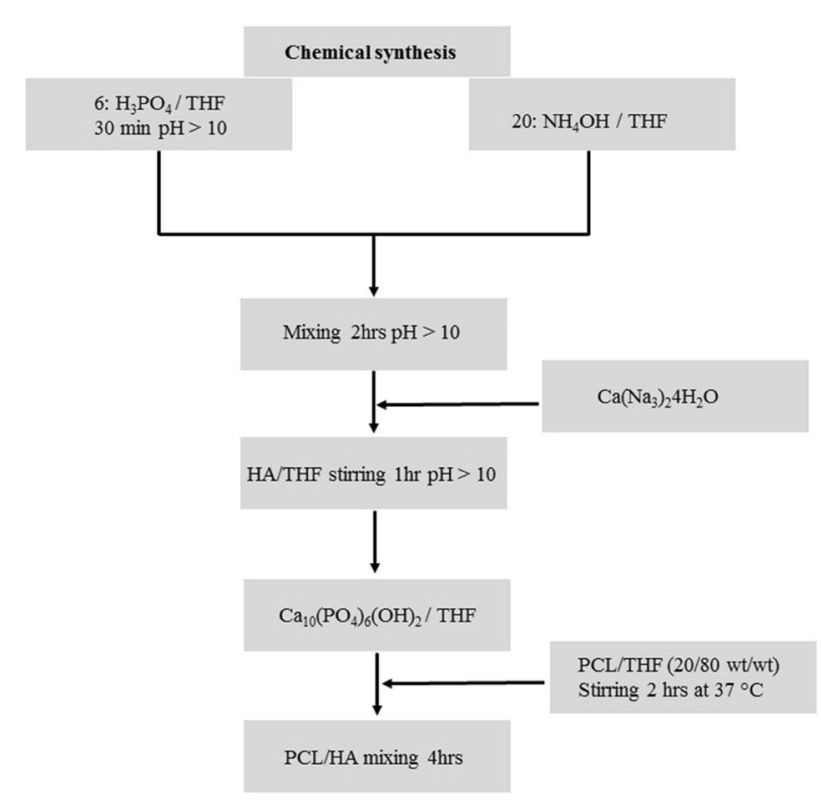

Fig. 2 Flow chart of PCL/HA scaffold preparation by chemical synthesis

and improved mechanical properties [42]. Zhu et al. prepared PCL/HA scaffolds with more than $93 \%$ porosity and $500 \mu \mathrm{m}$ pore diameters. They were able to control the porosity based on the shape and the amount of the porogens added [43]. With the availability a wide range of porogens, it is possible to generate pore sizes of $50-400 \mu \mathrm{m}$ with a reasonable degree of control. The scaffolds have interconnected pore structures with a pore size of $600 \mu \mathrm{m}$ [44]. The pore size of the PCL/HA scaffold was similar to the human trabecular bone $(300-1000 \mu \mathrm{m})$. Thadavirul et al. reported that PCL/HA composites treated with $\mathrm{NaOH}$, showed a well-defined interconnected pores, increased cell proliferation, high water absorption capacity, high bone matrix deposition, and improved hydrophilicity of the scaffold [45]. A systematic study has been performed, by loading three different HA concentrations $(13,20$, and 26 vol \%) in PCL-based composites, for improving the mechanical properties [46]. The HA nanoparticles incorporation within PCL composites increases cell differentiation, but it decreases the porosity and cell proliferation in the scaffolds [44]. In 14 days of cell culture, MTT assay, Alkaline phosphatase (ALP) activity for cell differentiation and total protein content were measured [47]. Compared to HA (13, 20, and $26 \mathrm{vol} \%)$, PCL/HA (90/10 vol\%) showed $85 \%$ porosity with the tensile modulus of up to $\pm 28 \mathrm{MPa}$ and, increased in compression modulus and stress upto \pm 30 and $15.6 \mathrm{MPa}$, respectively [42]. Guarino et al. described of MSCs seeded onto porous PCL/HA composites scaffolds and cultured in an osteogenic medium for 1-5 weeks. In 3-4 weeks, MSCs were able to adhere and grow on composite substrates, but the small effect of signals on the biological response was evaluated in MSC cell culture.
To overcome this problem, a pre-osteoblastic cell line (MC3T3-E1) has been used, showing a better cell adhesion and enhanced pre-osteoblast response on PCL/HA 3D scaffolds developed by this method. Porous PCL/HA composites are potential biomaterials for bone substitution, which exercise a beneficial influence on structural characteristics [46]. Compared to the other methods, scaffolds with interconnected networks, defined pore size, and increasing porosity can produce a greater degree of control so that the mechanical strength and the biological response can be maximized [48, 49]. Although the leaching method has defined shape, salt particles led to poor interconnection during the scaffold fabrication, and this may not provide optimal scaffold permeability in vitro for cell distribution.

\subsection{Sol-gel method}

In the sol-gel process, the particle size is directly controlled by the interaction between calcium and phosphate with nonalkoxide, calcium nitrate tetrahydrate, ammonia, and phosphoric acid as precursor materials under controlled temperature and $\mathrm{pH}$ conditions (Fig. 2) [50-52]. Raucci et al. synthesized composite biomaterial made up of HA/PCL (25/75 and 40/60 w/w) by sol-gel method using calcium nitrate tetrahydrate and di-phosphorous pentoxide as precursors, with ethanol and tetrahydrofuran as the solvent at room temperature. Further, the addition of salt as a porogen with a defined size range $(210-300 \mu \mathrm{m})$ showed a porous structure of $88 \%$. Later, a composite scaffold (PCL/HA) was treated in the simulated body fluid (SBF) in a controlled $\mathrm{pH}$ (6.5) environment and observed under SEM [53]. It forms apatite from the distribution of HA particles in the scaffold and the coating presence was stained with $0.5 \%$ trypan blue. The composite scaffold improves the hMSC differentiation towards the osteoblast phenotype observed in ALP activity [54]. Costa et al. studied HA nanorods synthesized by a sol-gel-hydrothermal process, which used amorphous calcium phosphate as a precursor material. PCL/ HA composites were produced by a mixture of HA powders with PCL resulting in a product of nanorod and nanowires HA/PCL scaffold. The composite scaffold was characterized by SEM, XRD, and FTIR and showed uniform distribution of HA nanorods within the PCL matrix. HA nanorods incorporated within PCL composites significantly increase the mechanical properties of Young's and compressive modulus from 193 to $665 \mathrm{MPa}$ and 230 to $487 \mathrm{MPa}$ respectively. The HA nanowires with PCL composite can be used for bone tissue engineering [55].

\subsection{Freeze drying}

Freeze-drying is a widely used conventional method for the fabrication of $3 \mathrm{D}$ scaffolds, making the solution to 


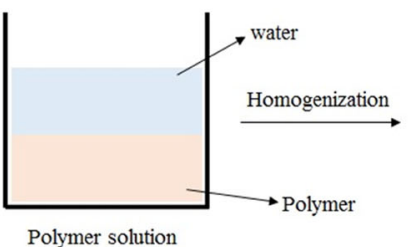

Fig. 3 Scheme representation of composite scaffold by freeze-drying method involves the preparation of an emulsion created by homogenization of a mixture of the polymer solution, and a water phase, where the continuous phase has the polymer-rich solvent and the

Table 1 Pore size, porosity, and compressive modulus of PCL/HA composite scaffolds produced with various HA contents $(0,5,10$, and 20 wt \%) [64]

\begin{tabular}{lcccc}
\hline HA content (wt. \%) & \multicolumn{1}{c}{5} & 10 & 20 \\
\hline Pore size $(\mu \mathrm{m})$ & $9.2 \pm 0.7$ & $8.5 \pm 0.4$ & $6.1 \pm 0.7$ & $4.2 \pm 0.8$ \\
Porosity (vol \%) & $83.0 \pm 0.6$ & $83.9 \pm 0.2$ & $84.5 \pm 0.2$ & $85.0 \pm 0.6$ \\
Compressive & $0.1 \pm 0.02$ & $1.2 \pm 0.07$ & $2.1 \pm 0.06$ & $2.7 \pm 0.08$ \\
modulus (MPa) & & & & \\
\hline
\end{tabular}

Table 2 Mechanical properties of the composite Scaffolds GEL/HA with a different weight percentage of PCL content [67]

\begin{tabular}{llllll}
\hline PCL content (wt. \%) & 0 & 20 & 30 & 40 & 50 \\
\hline Elastic modulus (MPa) & 8 & 16 & 19 & 20.5 & 23.5 \\
Stress (MPa) & 1.83 & 3.13 & 3.40 & 3.71 & 3.73 \\
Stiffness $(\mathrm{K} / \mathrm{mm})$ & 38 & 79 & 93 & 114 & 131 \\
\hline
\end{tabular}

freeze at low temperature $\left(-70\right.$ to $\left.-80^{\circ} \mathrm{C}\right)$, over the primary drying process in which the pressure is lowered through a partial vacuum in the chamber, while water and solvent in the material are removed by sublimation (Fig. 3) [56-59]. Jain et al. used chitosan, PCL, and HA to fabricate porous 3D scaffolds to achieve a pore size ranging between 50 and $200 \mu \mathrm{m}$, and $90 \%$ of porosity. These composite scaffolds enhanced the mechanical properties, cell proliferation, differentiation, biodegradability, and improved osteoconductivity [60-63]. Choi et al. produced PCL/HA porous scaffolds using freezing drying methods with different HA contents $(0,5,10$, and 20 wt \%). The HA particles uniformly distributed in the PCL matrix showed significant improvement in pore size, porosity, and mechanical properties (Table 1). The MC3T3 cells were seeded on the porous scaffold with different HA contents. After day 1, PCL/HA scaffolds showed that the MC3T3 cells attached themselves on the surface and differentiated there. Still, the highest cells proliferation was observed in composite PCL/HA scaffolds with $20 \mathrm{wt} \% \mathrm{HA}$ [64]. Sharon et al. incorporated the composite PCL/HA scaffold with conductive dispersed phase is water, quickly cooling the emulsion to catch in the liquid phase construction, and eliminating the solvent and water by freeze-drying
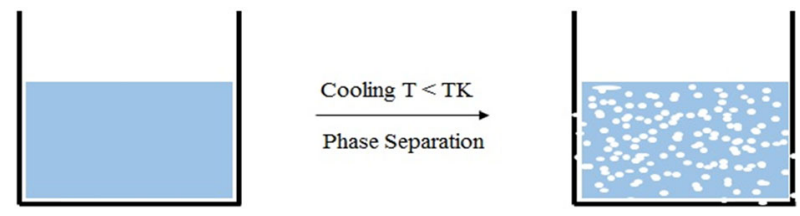

Fig. 4 Scheme composite scaffold by thermal induced phase separation method (TIPS) for scaffolds designing consists of quenching the polymer solution under the solvent's freezing point (Tk) and enforcing liquid-liquid separation to shape two phases: a polymer-rich phase and a polymer-poor phase. The polymer-rich phase solidifies and the polymer poor phase crystallizes. Subsequent removal of crystals by sublimation leaves a porous polymer scaffold

polymer polypyrrole (PPY) to increase the pore size from 50 to $250 \mu \mathrm{m}$ and the average pore size was $130.4 \mu \mathrm{m}$ compared to PCL and PCL/HA scaffolds which had an average pore size 123.7 and $91.6 \mu \mathrm{m}$ respectively. Also, composite PCL/HA/PPY scaffolds improved mechanical strength, biodegradability, and mediated electrical stimulation to enhance bone regeneration $[65,66]$. Although scaffold porosity increases, the mechanical properties decreases. To improve the mechanical strength Hamlekhan et al., studied composite PCL/HA/ Gelatin prepared by solvent casting combined with the freeze-drying method, showing that the scaffolds were mechanically effective due to an increase in the stress, stiffness, and elastic modulus (Table 2). SBF and the cytotoxicity studies reported the gradual development of the apatite layer and biocompatibility. These results indicated that the fabricated scaffold possesses the prerequisites for forming/acting as substitute for bone tissue [67].

\subsection{Thermally Induced phase separation (TIPS)}

TIPS process consists of quenching the polymer solution under the solvent freezing point and enforcing liquid-liquid separation (Fig. 4) [68, 69]. In this method, HA nanoparticles were incorporated in the PCL polymer solution to make composite scaffolds (PCL/HA). HA nanoparticles were uniformly distributed in the PCL polymer matrix and observed by SEM. The PCL/HA 
Fig. 5 Scheme of electrospining process for composite scaffold fabrication through fiber deposition

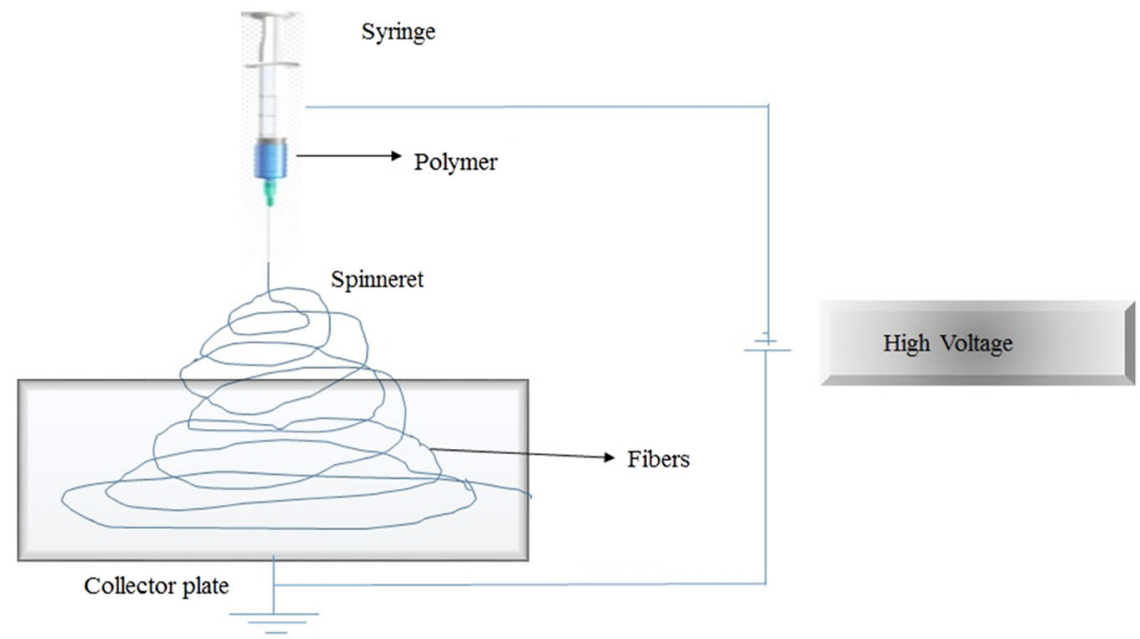

\begin{tabular}{llllll}
\hline AM techniques & Porosity $(\%)$ & $\begin{array}{l}\text { Compressive } \\
\text { strength }(\mathrm{MPa})\end{array}$ & Yield strength $(\mathrm{MPa})$ & Wt.\% of HA & Ref. \\
\hline FDM & 26 & 15 & 80 & 30 & [97] \\
DIW & - & $24 \pm 5$ & $110 \pm 20$ & 70 & {$[98]$} \\
SLS & 37 & 3.2 & 67 & 30 & {$[99]$} \\
3D printing & - & 7 & 40 & $(0: 100-50: 50)$ & {$[100]$} \\
\hline
\end{tabular}

Table 3 HA constructs processed by additive manufacturing techniques
$5.6 \mu \mathrm{m}$. The tensile strength of the fibrous scaffold increased to 3.6 and $3.8 \mathrm{MPa}$ with respect to HA content $(0.5$ and $1.0 \%$ $\mathrm{w} / \mathrm{v})$. Human osteoblasts ( $\mathrm{SaOS} 2)$ cells were cultured on the fibrous scaffold, and the result of cell viability (MTT assay) together with cell differentiation (ALP assay), suggested the biocompatiblity and stimulate cell differentiation [75]. Polini et al., found that the incorporation of either HA or TCP into the PCL nanofibers supports bone mineralization, cell viability, and cell growth. Quantitative analysis of mRNA expression on Runx-2 resulted in a strong stimulation of osteogenic differentiation; and bone sialoprotein was associated with bone mineralized tissue differentiation, in the absence of osteogenic supplements. The nanofibrous structure and the chemical composition of the scaffolds regulate the hMSCs differentiation [76]. In order to increase the mechanical properties of scaffolds, Catledge et al., designed a novel triphasic nanofibrous scaffold from a mixture of PCL/ nHA/Collagen ratio of 50/30/20, respectively. The triphasic scaffold stained with calcein showed uniform distribution of bone-like apatite particles on the polymer matrix with agglomeration. The triphasic scaffold improves the mechanical properties of Young's modulus by $2.7 \mathrm{GPa}$ [77]. Silicate-containing hydroxyapatite ( $\mathrm{SiHA})$ is widely studied for the fabrication of scaffolds, which may improve the bioactivity and osteogenic potential $[78,79]$. Shkarina et al., designed and fabricated 3D composite scaffolds (SiHA/PCL) with a predetermined fibers orientation, randomly oriented 


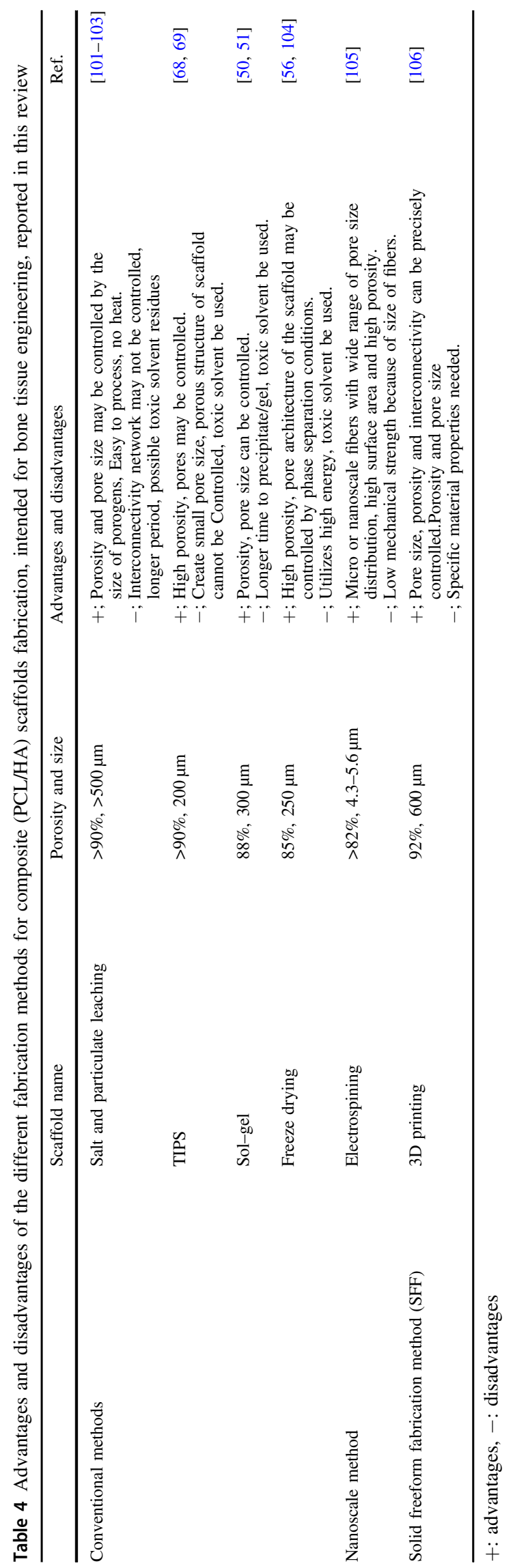

(rPCL-SiHA) and well-aligned (wPCL-SiHA), to mimic $\mathrm{ECM}$ and characterized by synchrotron $\mu \mathrm{CT}$. A significant increase in the MSCs proliferation and differentiation on wPCL-SiHA, rather than rPCL-SiHA, was observed after 10 days of cell culture [80].

\subsection{Rapid prototyping}

Rapid prototyping technique (RP) is an advanced technique for the fabrication of well-designed 3D scaffolds with the interconnected porous structure associated with biomolecules and cells [81, 82]. This techniques can fabricate composite PCL/HA scaffolds for repairing damaged bone, specifically, in the analysis of the mechanical properties [83]. Powder-based 3D printing (3DP) is an alternative method to fabricate scaffolds, but the poor mechanical properties restrict their application in bone tissue engineering. Kim et al., prepared calcium sulfate hemihydrate scaffold printed using a 3DP. The fabricated 3DP calcium sulfate hemihydrate powder was transformed into HA upon being treated with ammonium phosphate solution. The scaffolds were coated with PCL polymer solution (5 and $10 \% \mathrm{w} / \mathrm{v})$ to significantly increase the mechanical strength to $46.86 \pm 1.19$ and $87.96 \pm 6.05 \mathrm{MPa}$ respectively and decrease the porosity of material compared with $5 \%$ PCL coated scaffolds. MG-63 cells cultured on $10 \% \mathrm{w} / \mathrm{v}$ of PCL coated HA loaded scaffold showed an increase in osteogenic genes expression, namely Col1A1, Runx2, OSX, and OC, as revealed by semi-quantitative RT-PCR analysis. MTT and ALP studies reported improved the cell attachment and proliferation on $10 \% \mathrm{w} / \mathrm{v}$ PCL coated scaffold [84]. To increase the porosity of the scaffolds. Park et al., designed and fabricated composite scaffolds with a shifted pattern structure (PCL/HA/SP) by 3D plotting system to improve cell adhesion. The PCL/ HA/SP scaffold shows a good interconnected network, highly regular pore size higher than $600 \mu \mathrm{m}$, and porosity of $92 \%$ with well-defined geometry. The scaffold with shifted pattern had denser structure than PCL/HA and PCL. MTT assay and ALP activity resulted in an increase of cell proliferation and differentiation in PCL/HA/SP compared to the PCL and PCL/HA scaffolds. The mechanical modulus of PCL/HA/ SP is not significantly higher than the PCL and PCL/HA scaffolds [83]. Shigang Wang et al., fabricated PCL/HA composite scaffold with a porous circular structure by using 3D printing technology [85]. To further improve the mechanical properties, Liao et al., fabricated the triblock polymer mPEG-PCL-mPEG (PCL) scaffold and mPEGPCL-mPEG/HA (PCL/HA) by solid free fabrication method [86]. The HA powder with a size of $100 \mu \mathrm{m}$ was incorporated with mPEG-PCL-mPEG (PCL) by 0.5 weight ratio. PCL/HA biocomposite scaffold showed an increase in pore size, porosity, and mechanical properties of 
$374.32 \pm 11.25 \mu \mathrm{m}, 80 \%$, and 18.38 MPa, respectively [87]. In a similar study by Kim et al., HA/PCL produced composite scaffold by NIPS method, with HA particles dispersing uniformly in a PCL solution induced by the exchange of the tetrahydrofuran and ethanol [88-93]. The process solidifies PCL/HA filaments to create the porous PCL/HA composite scaffold [94]. These PCL/HA filaments were constructed by 3D design in a layer-by-layer separated by highly porous material. The addition of HA particles to the PCL polymer has shown significant increase in mechanical properties, and the ability to form apatite. The MTT and ALP studies have shown an increase in cell proliferation and differentiation of PCL/HA scaffolds [95]. Table 3 shows the morphological, mechanical, and compositional features of PCL/HA-reinforced scaffolds fabricated by employing different additive manufacturing techniques: FDM, DIW, SLS, and 3D printing [96]. Advantages and disadvantages of fabrication methods applied for generation of porous composite scaffolds PCL/ HA are shown in Table 4.

\section{Conclusions}

Tissue engineering emerges as a promising strategy to overcome the challenges of conventional bone graft treatments. PCL-based composite will be a promising biomaterial for bone tissue engineering. The combination of PCL with HA nanoparticles can result in 3D scaffold as suitable bone graft substitutes, owing to their properties such as mechanical strength, pore architecture, osteoconductivity, and osteoinductivity. PCL/HA composite scaffolds are non-toxic for cells and enhance the slow degradation, which may be suitable for bone tissue engineering. The conventional fabrication methods such as sol-gel, solvent casting, and particulate leaching, electrospinning, freeze-drying, and TIPS cannot control the pore architecture, geometry, or pore distributions of the scaffolds. On the contrary, rapid prototyping methods have been introduced to overcome the problem of conventional methods, developing customized scaffolds with high porosity, pore architecture control, ideal geometrical shape, mechanical properties, internal morphology, and mass transport properties. Specifically, the rapid prototype methods are able to fabricate the scaffolds in a layer by layer, starting from a 3D computer model of the scaffold designed with specific characteristics. The 3D plotting method is useful in the fabrication of porous PCL/HA composite scaffolds with controlled micro/macroporous structure, mechanical properties, bioresorption along with inherent osteogenic features, which are crucial for bone tissue regeneration.

Acknowledgements The authors thank National Institute of Technology, Warangal for providing research facility. SM thanks Ministry of
Human Resources and Development, Government of India, New Delhi for providing fellowship. The authors thank Dr. Vishwanathan M and Santanu Sasidharan for helping in proofreading the manuscript.

\section{Compliance with ethical standards}

Conflict of interest The authors declare no competing interests.

Publisher's note Springer Nature remains neutral with regard to jurisdictional claims in published maps and institutional affiliations.

Open Access This article is licensed under a Creative Commons Attribution 4.0 International License, which permits use, sharing, adaptation, distribution and reproduction in any medium or format, as long as you give appropriate credit to the original author(s) and the source, provide a link to the Creative Commons license, and indicate if changes were made. The images or other third party material in this article are included in the article's Creative Commons license, unless indicated otherwise in a credit line to the material. If material is not included in the article's Creative Commons license and your intended use is not permitted by statutory regulation or exceeds the permitted use, you will need to obtain permission directly from the copyright holder. To view a copy of this license, visit http://creativecommons. org/licenses/by/4.0/.

\section{References}

1. Bandyopadhyay A, Bose S. Characterization of Biomaterials. Elsevier Inc. 2013;1.

2. Mouriño V, Boccaccini AR. Bone tissue engineering therapeutics: controlled drug delivery in three-dimensional scaffolds. J. R. Soc. Interface. 2010;7:209-27.

3. Langer R, Vacanti JP. Tissue engineering. Science 1993; 260:920-6. 10.1126/science. 8493529

4. Moore WR, Graves SE, Bain GI. Synthetic bone graft substitutes. ANZ J Surg. 2001;71:354-61.

5. Khojasteh A, Behnia H, Dashti SG, Stevens M. Current trends in mesenchymal stem cell application in bone augmentation: a review of the literature. J Oral Maxillofac Surg. 2012;70:972-82. https://doi.org/10.1016/j.joms.2011.02.133.

6. Tabatabaei FS, Motamedian SR, Gholipour F, Khosraviani K, Khojasteh A. Craniomaxillofacial bone engineering by scaffolds loaded with. Stem Cells. 2012;30:113-30.

7. Webster TJ, Waid MC, McKenzie JL, Price RL, Ejiofor JU. Nano-biotechnology: carbon nanofibers as improved neural and orthopedic implants. Nanotechnology. 2004;15:48-54.

8. Ma K, Chan CK, Liao S, Hwang WYK, Feng Q, Ramakrishna S. Electrospun nanofiber scaffolds for the rapid and rich capture of bone marrow-derived hematopoietic stem cells. Biomaterials. 2008;29:2096-103.

9. Nerem RM. Tissue engineering in the USA. Med Biol Eng Comput. 1992;30:8-12.

10. Roseti L, Parisi V, Petretta M. Scaffolds for bone tissue engineering: state of the art and new perspectives. Mater Sci Eng C. 2017;78:1246-62.

11. Aldana AA, Abraham GA. Current advances in electrospun gelatin-based scaffolds for tissue engineering applications. Int $\mathrm{J}$ Pharmaceutics. 2017;2:441-53.

12. Sultana N. Scaffolds for tissue engineering. MRS Bull. 2003;4:301-6.

13. Karageorgiou V, Kaplan D. Porosity of 3D biomaterial scaffolds and osteogenesis. Biomaterials. 2005;26:5474-91. 
14. Xue W, Krishna BV, Bandyopadhyay A, Bose S. Processing and biocompatibility evaluation of laser processed porous titanium. Acta Biomaterialia. 2007;3(6):1007-18.

15. Otsuki B, Takemoto M, Fujibayashi S, Neo M, Kokubo T, Nakamura T. Pore throat size and connectivity determine bone and tissue ingrowth into porous implants: three-dimensional micro-CT based structural analyses of porous bioactive titanium implants. Biomaterials. 2006;27:5892-900.

16. Doshi J, Reneker DH. Electrospinning process and application of electrospun fibers. J Electrostat. 1995;35:151-60.

17. Ma PX, Langer R. Fabrication of biodegradable polymer foams for cell transplantation and tissue engineering. Methods Mol Med. 1999;18:47-56.

18. Ma PX. Biomimetic materials for tissue engineering. Adv Drug Deliv Rev. 2008;60:184-98. https://doi.org/10.1016/j.addr.2007. 08.041.

19. Fröhlich M, Grayson WL, Wan LQ, Marolt D, Drobnic M, Vunjak-Novakovic G. Tissue-engineered bone grafts: biological requirements, tissue culture, and clinical relevance. Curr Stem Cell Res Ther. 2008;3:254-64. https://doi.org/10.2174/15748.

20. Mano JF, Reis RL. Osteochondral defects: present situation and tissue engineering approach. Tissue Eng Regenerative Med. 2007;1:261-73.

21. Kachal S, Putnam AJ. Mesenchymal stem cells from adipose and bone marrow promote angiogenesis via distinct cytokine and protease expression mechanisms. Angiogenesis 2011;14:45-59.

22. Kobolak J, Dinnyes A, Memic A, Khademhosseini A, Mobasheri A. Mesenchymal stem cells: Identification, phenotypic characterization, biological properties and potential for regenerative medicine through biomaterial micro-engineering of their niche. Methods. 2016;99:62-8. https://doi.org/10.1016/j.ymeth.2015.09.016.

23. Undale AH, Westendorf JJ, Yaszemski MJ, Khosla S. Mesenchymal stem cells for bone repair and metabolic bone diseases. Mayo Clin Proc. 2009;10:893-902.

24. Kraeutler MJ, Belk JW, Purcell JM, McCarty EC. Microfracture versus autologous chondrocyte implantation for articular cartilage lesions in the knee: a systematic review of 5-year outcomes. Am J Sports Med. 2017;4:995-9.

25. Amini AR, Laurencin CT, Nukavarapu SP. Bone tissue engineering: recent advances and challenges. Crit Rev Biomed Eng. 2012;40:363-408.

26. Zhang $X$, Chang $W$, Lee $P$, Wang $Y$, Yang $M$, Li J. et al. Polymer-ceramic spiral structured scaffolds for bone tissue engineering: effect of hydroxyapatite composition on human fetal osteoblasts. PLoS One. 2014;9:e85871. https://doi.org/10. 1371/journal.pone.0085871.

27. Boccaccini AR, Blaker JJ. Bioactive composite materials for tissue engineering scaffolds. Expert Rev Med Devices. 2005;2:303-17.

28. Landers R, Hu“bner U, Schmelzeisen R, Mu“lhaupt R. Rapid prototyping of scaffolds derived from thermoreversible hydrogels and tailored for applications in tissue engineering. Biomaterials. 2002;23:4437-47.

29. Shor L, Gu"ceri S, Wen X, Gandhi M, Sun W. Fabrication of three-dimensional polycaprolactone/hydroxyapatite tissue scaffolds and osteoblast-scaffold interactions in vitro. Biomaterials. 2007;28:5291-7.

30. Woodruff MA, Hutmacher DW. The return of a forgotten polymer-Polycaprolactone in the 21st century. Prog Polym Sci. 2010;35:1217-56

31. LE Ray AM, Gautier H, Bouler JM, Weiss P, Merle C. A new technological procedure using sucrose as porogen compound to manufacture porous biphasic calcium phosphate ceramics of appropriate micro and macrostructure. Ceram Int. 2010;36: 93-101.
32. Liu YX, Kim JH, Young D, Kim S, Nishimoto SK, Yang YZ. Novel template-casting technique for fabricating beta-tricalcium phosphate scaffolds with high interconnectivity and mechanical strength and in vitro cell responses. J Biomed Mater Res Part A. 2010;92A:997-1006. https://doi.org/10.1002/Jbm.A.32443.

33. Dorati R, Colonna C, Genta I. Effect of porogen on the physicochemical properties and degradation performance of PLGA scaffolds. Polym Degrad Stab. 2010;95:694-701.

34. Boccaccini AR, Notingher I, Maquet V. Bioresorbable and bioactive composite materials based on polylactide foams filled with and coated by BioglassR particles for tissue engineering applications. J Mater Sci Mater Med. 2003;14:443-50.

35. Shor L, Guceri S, Wen X, et al. Fabrication of three-dimensional polycaprolactone/ hydroxyapatite tissue scaffolds and osteoblastscaffold interactions in vitro. Biomaterials 2007;28:5291-7.

36. Suh SW, Shin JY, Kim J, et al. Effect of different particles on cell proliferation in polymer scaffolds using a solvent-casting and particulate leaching technique. ASAIO J. 2002;48:460-4.

37. Yang Q, Chen L, Shen X, Zhiqing T. Preparation of polycaprolactone tissue engineering scaffolds by improved solvent casting/particulate leaching method. J Macromol Sci B Phys. 2006;45:1171-81.

38. Liu H, Han C, Dong L. Study on the cell structure and compressive behavior of biodegradable poly ( $\varepsilon$-caprolactone) foam. Polym Eng Sci. 2008;48:2432-8.

39. Shin M, Abukawa H, Troulis MJ, Joseph P. Vacanti. Development of a biodegradable scaffold with interconnected pores by heat fusion and its application to bone tissue engineering. $\mathrm{J}$ Biomed Mater Res A. 2008;84:702-9.

40. Salehi R, Aghazadeh M, Rashidi M, Samadi N, Salehi Sh, Davaran $\mathrm{S}$, et al. Bioengineering of dental pulp stem cells in a microporous PNIPAAm-PLGA scaffold. Int $\mathbf{J}$ Polym Mater Polym Biomater. 2014;63:767-76.

41. Laschke M, Strohe A, Menger M, Suaste-Olmos F, GonzálezAlva $\mathrm{P}$, Altobelli $\mathrm{R}$, et al. In vitro and in vivo evaluation of a novel nanosize hydroxyapatite particles/poly (ester-urethane) composite scaffold for bone tissue engineering. Acta Biomaterialia. 2010;6:2020-7.

42. Fabbri P, Bondioli F, Messori M, Bartoli C, Dinucci D, Chiellini $\mathrm{F}$, et al. Porous scaffolds of polycaprolactone reinforced with in situ generated hydroxyapatite for bone tissue engineering. J Mater Sci: Mater Med. 2010;21:343-51.

43. Zhu N, Chen X. Biofabrication tissue scaffolds. Adv Biomater Biomed Appl. 2013;12:315-28.

44. Hyun Y-T, Kim S-E, Heo S-J, Shin J-W. Characterization of PCL/HA Composite Scaffolds for Bone Tissue Engineering. Key Eng Mater. 2007;342-3:109-12.

45. Thadavirul N, Pavasant P, Supaphol P. Improvement of dualleached polycaprolactone porous scaffolds by incorporating with hydroxyapatite for bone tissue regeneration. J Biomater Sci Polym Ed. 2008;25:17.

46. Chuenjitkuntaworn B, Inrung W, Damrongsri D, Mekaapiruk K, Supaphol P, Pavasant P. Polycaprolactone/Hydroxyapatite composite scaffolds: preparation, characterization, and in vitro and in vivo biological responses of human primary bone cells. $\mathrm{J}$ Biomed Mater Res Part A. 2010;94A:241-51. https://doi.org/10. 1002/Jbm.A.32657.

47. Heo SJ, Kim SE, Hyun YT, Kim DH, Lee HM, Hwang YM, et al. In Vitro Evaluation of Polycaprolactone/Hydroxyapatite composite as scaffolds for bone tissue engineering with human bone marrow stromal cells. Key Eng Mater. 2007;342-343:369-72.

48. Sin D, Miao X, Liu G, Fan Wei, Gary Chadwick, Cheng Yan, Thor Friis. Polyurethane(PU) scaffolds prepared by solvent casting/particulate leaching (SCPL) combined with centrifugation. Mater Sci Eng C. 2010;30:78-85. 
49. Sampath UGTM, Ching YC, Chuah CH, Sabariah JJ, Lin P-C. Fabrication of porous materials from natural/synthetic biopolymers and their composites. Materials. 2016;9:991. https://doi. org/10.3390/ma9120991.

50. Liu DM, Troczynski T, Tseng WJ. Water-based sol-gel synthesis of hydroxyapatite process development. Biomaterials 2001;22:1721.

51. Laschke M, Strohe A, Menger M, Alini M, Eglin D. In vitro and in vivo evaluation of a novel nanosize hydroxyapatite particles/ poly(ester-urethane) composite scaffold for bone tissue engineering. Acta Biomaterialia. 2010;6:2020-7.

52. Raucci MG, Guarino V, Ambrosio L. Hybrid composite scaffolds prepared by sol-gel method for bone regeneration. Compos. Sci. Technol. 2010;70:1861-68.

53. Tanahashi M, Hata K, Kokubo T, Minoda M, Nakamura T, Yamamuro T. In: Yamamuro T, Kokubo T, Nakamuro T, Bioceramics. 1992;5:57.

54. Raucci MG, D’Antò V, Guarino V, Sardella E, Zeppetelli S, Favia P, et al. Biomineralized porous composite scaffolds prepared by chemical synthesis for bone tissue regeneration. Acta Biomaterialia. 2010;6:4090-9.

55. Costa DanielO, Jeffrey Dixon S, Rizkalla AminS. One- and Three-Dimensional growth of hydroxyapatite nanowires during sol-gel-hydrothermal Synthesis. ACS Appl Mater Interfaces 2012;4:1490-9.

56. Liu C, Xia Z, Czernuszka JT. Design and development of threedimensional scaffolds for tissue engineering. Chem Eng Res Des. 2007;85:1051-64.

57. Pisano R, Barresi AA, Fissore D. Innovation in monitoring food freeze drying. Dry Technol. 2011;29:1920-31.

58. Ganguly A, Nail SL, Alexeenko AA. Rarefied gas dynamics aspects of pharmaceutical freeze-drying. Vacuum 2012;86: 1739-47.

59. Liu HH, Nakagawa K, Kato DI, Chaudhary D, Tade MO. Enzyme encapsulation in freeze-dried bionanocomposites prepared from chitosan and xanthan gum blend. Mater Chem Phys. 2011;129:488-94.

60. Jain KG, Mohanty S, Ray AR, Malhotra R, Airan B. Culture \& differentiation of mesenchymal stem cell into osteoblast on the degradable biomedical composite scaffold: in vitro study. Indian J Med Res. 2015;142:747-58.

61. Clyne AM. Thermal processing of tissue engineering scaffolds. J Heat Transf. 2011;133:034001.

62. Chen L, Hu J, Shen X, Tong H. Synthesis and characterization of chitosan-multiwalled carbon nanotubes/hydroxyapatite nanocomposites for bone tissue engineering. J Mater Sci. 2013;24:1843-51.

63. Kim JY, Lee TJ, Cho DW, Kim BS. Solid free-form fabricationbased PCL/HA scaffolds fabricated with a multi-head deposition system for bone tissue engineering. J Biomater Sci, Polym Ed. 2010;21:951-62.

64. Choi W-Y, Kim H-E, Koh Y-H. Production, mechanical properties, and in vitro biocompatibility of highly aligned porous PCL/HA scaffolds. J Porous Mater. 2013;20:701-8.

65. Balint R, Cassidy NJ, Cartmell SH. Conductive Polymers: Towards A Smart Biomaterial for Tissue Engineering. Acta Biomaterialia. 2014;10:2341-53.

66. Sharon KJU, Naznin S. Fabrication and characterization of PCL/ HA/PPY composite scaffold using freeze-drying technique. J Teknol. 2016;78:89-9.

67. Hamlekhan A, Mozafari M, Nezafati N, Azami M, Hadipour H. A proposed fabrication method of novel PCL-GEL-HA nanocomposite scaffolds for bone tissue engineering applications. Adv Compos Lett. 2010;19:4.

68. Lee K-WD, Chan PK, Feng X. Morphology development and characterization of the phase-separated structure resulting from the thermal-induced phase separation phenomenon in polymer solutions under a temperature gradient. Chem Eng Sci. 2004;59:1491-504.

69. Rowlands AS, Lim SA, Martin D, Cooper-White JJ. Polyurethane/poly (lactic-co-glycolic) acid composite scaffolds fabricated by thermally induced phase separation. Biomaterials. 2007;28:2109-21.

70. Sultana N, Khan TH. Polycaprolactone scaffolds and HA/PCL composite scaffolds for bone tissue engineering. J. Bionanosci. 2013. https://doi.org/10.1166/jbns.2013.1112.

71. Guan J, Fujimoto KL, Sacks MS, et al. Preparation and characterization of highly porous, biodegradable polyurethane scaffolds for soft tissue applications. Biomaterials. 2005;26: 3961-71.

72. Salerno A, Domingo C. Pore structure properties of scaffolds constituted by aggregated microparticles of PCL and PCL-HA processed by phase separation. J Porous Mater. 2015;22:425-35. https://doi.org/10.1007/s10934-015-9911-2.

73. Dhand C, Theng Ong S, Dwivedi N, Marrero Diaz S, Jayarama Reddy V, Balchander N, et al. Bio-inspired in situ crosslinking and mineralization of electrospun collagen scaffolds for bone tissue engineering. Biomaterials. 2016;104:323-38.

74. Zhu N, Chen X. Biofabrication of Tissue Scaffolds, in a book entitled, "Advances in Biomaterials Science and Biomedical Applications", Rosario Pignatello, IntechOpen. https://doi.org/ $10.5772 / 54125$.

75. Wutticharoenmongkol P, Sanchavanakit N, Pavasant P, Supaphol P. Novel Bone Scaffolds of electrospun polycaprolactone fibers filled with nanoparticles. J Nanosci Nanotechnol. 2006;6:514-22.

76. Polini A, Pisignano D, Parodi M, Quarto R, Scaglione S. Osteoinduction of human mesenchymal stem cells by bioactive composite scaffolds without supplemental osteogenic growth factors. PLoS ONE. 6:e26211. https://doi.org/10.1371/journal. pone.0026211.

77. Catledge SA, Clem WC, Shrikishen N, Chowdhury S, Stanishevsky AV, Koopman M, et al. An electrospun triphasic nanofibrous scaffold for bone tissue engineering. Biomed Mater. 2007:2:142-50.

78. Gorodzha SN, Surmeneva MA, Surmenev RA, Gribennikov MV, Pichugin VF, Sharonova AA, et al. Wettability of Thin Silicate-Containing Hydroxyapatite Films Formed by RFMagnetron Sputtering. Russ Phys J. 2014;56:1163-9.

79. Surmeneva MA, Kovtun A, Peetsch A, Goroja SN, Sharonova AA, Pichugin VF, et al. Preparation of a silicate-containing hydroxyapatite-based coating by magnetron sputtering: structure and osteoblast-like MG63 cells in vitro study. RSC Adv. 2013;3:11240

80. Shkarina S, Shkarin R, Weinhardt V, Melnik E, Gabriele V, Vacun G, et al. 3D biodegradable scaffolds of polycaprolactone with silicate containing hydroxyapatite microparticles for bone tissue engineering: high-resolution tomography and in vitro study. Sci Rep. 2018;8:8907. https://doi.org/10.1038/s41598018-27097-7.

81. Yu D, Li Q, Mu X, Chang T, Xiong Z. Bone regeneration of critical calvarial defect in goat model by PLGA/TCP/rhBMP2 scaffolds prepared by low-temperature rapid-prototyping technology. Int J Oral Maxillofac Surg. 2008;37:929-34.

82. Khalil S, Sun W. Bioprinting endothelial cells with alginate for 3D tissue constructs. J Biomech Eng. 2009;131:111002.

83. Su Park A, Su Hee L, Wan Doo K. Fabrication of porous PCL/ HA blend scaffolds using a 3D plotting system for bone tissue engineering. Bioprocess Biosyst Eng. 2011;34:505-13.

84. Kim B-S, Yang S-S, Park H, Lee S-H, Cho Y-S, Lee J. Improvement of mechanical strength and osteogenic potential of calcium sulfate-based hydroxyapatite 3-dimensional printed scaffolds by $\varepsilon$-polycarbonate coating. J Biomater Sci. https://doi. org/10.1080/09205063.2017.1312059. 
85. Wang S, Fan Y, Jiang S. 3D Printing PCL-HA one tissue engineering scaffold and its performance test. J. Residuals Sci. Technol. 2016;14:271.

86. Jiang CP, Chen YY, Hsieh MF, Lee HM. Solid freeform fabrication and in-vitro response of osteoblast cells of mPEG-PCLmPEGbone scaffolds. Biomed Microdevices. 2013;15:369-79.

87. Liao H-T, Chen Y-Y, Lai Y-T, Hsieh M-F, Jiang C-P. The osteogenesis of bone marrow stem cells on mPEG-PCL-mPEG/ Hydroxyapatite composite scaffold via solid freeform fabrication. BioMed Res Int. 2014;321549:13pp.

88. Guillen RG, Pan Y, Li M, Hoek EMV. Preparation and characterization of membranes formed by non-solvent induced phase separation: a review. Ind Eng Chem Res. 2011;50:3798-817.

89. Chiono V, Ciardelli G, Vozzi G, Sotgiu MG, Vinci B, Domenici C, et al. Poly(3-hydroxybutyrate-co-3-hydroxyvalerate)/poly("-caprolactone) blends for tissue engineering applications in the form of hollow fibers. J Biomed Mater Resour A. 2008;85:938-53.

90. Yen C, He H, Lee LJ, Ho WSW. Synthesis and characterization of nanoporous polycaprolactone membranes via thermally- and nonsolvent-induced phase separations for biomedical device application. J Membr Sci. 2009;343:180-8.

91. Bettahalli NMS, Steg H, Wessling M, Stamatialis D. Development of poly (L-lactic acid) hollow fiber membranes for artificial vasculature in tissue engineering scaffolds. J Membr Sci. 2011;371:117-26.

92. Diban N, Haimi S, Bolhuis-Versteeg L, Teixeira S, Miettinen S, Poot A, et al. Development and characterization of polycaprolactone hollow fiber membranes for vascular tissue engineering. J Membr Sci. 2013;438:29-37.

93. Lei B, Shin KH, Noh DY, Jo IH, Koh YH, Choi WY, et al. Nanofibrous gelatin/silica hybrid scaffolds mimicking native extracellular matrix (ECM) using thermally induced phase separation. J Mater Chem. 2012;22:14133-40.

94. Zein I, Hutmacher DW, Tan KC, Teoh SH. Fused deposition modeling of novel scaffold architectures for tissue engineering applications. Biomaterials. 2002;23:1169-85.

95. Kim J-W, Shin K-H, Koh Y-H, Hah MJ, Moon J, Kim H-E. Production of PCL/HA composite scaffolds with a tailored macro/micro-porous structure, high mechanical properties, and excellent bioactivity. Materials. 2017;10:1123. https://doi.org/10. 3390/ma10101123.

96. Milazzo M, Negrini NC, Scialla S, Marelli B, Farè S, Danti S, et al. Additive manufacturing approaches for hydroxyapatitereinforced composites. Adv. Funct. Mater. 2019. https://doi.org/ 10.1002/adfm.201903055.

97. Xu N, Ye X, Wei D, Zhong J, Chen Y, Xu G, et al. 3D artificial bones for bone repair prepared by computed tomography-guided fused deposition modeling for bone repair. ACS Appl. Mater. Interfaces 2014;6:14952-63.

98. Russias J, Saiz E, Deville S, Gryn K, Liu G, Nalla RK, et al. Fabrication and in vitro characterization of three-dimensional organic/inorganic scaffolds by robocasting. J. Biomed. Mater. Res. Part A 2007;83:434-45.

99. Eosoly S, Brabazon D, Lohfeld S, Looney L. Selective laser sintering of hydroxyapatite/poly-epsilon-caprolactone scaffolds. Acta Biomaterialia. 2010;6:2511-7.

100. Liu D, Nie W, Li D, Wang W, Zheng L, Zhang J, et al. 3D printed PCL/SrHA scaffold for enhanced bone regeneration. Chem. Eng. J. 2019;362:269-79.

101. Yang S, Leong K, Du, Chua C. The design of scaffolds for use in tissue engineering. Part I. Traditional factors. Tissue Eng. 2001;7:679-89.

102. Mikos AG, Temenoff JS. Formation of highly porous biodegradable scaffolds for tissue engineering. Electron J Biotechnol. 2000;3:114-9.

103. Shah Mohammadi M, Bureau MN, Nazhat SN. Polylactic acid biomedical foams for tissue engineering. Biomed Foams Tissue Eng Appl. 2014;313-34.

104. Ma PX. Scaffolds for tissue fabrication. Mater Today. 2004;7:30-40.

105. Weigel T, Schinkel G, Lendlein A. Design and preparation of polymeric scaffolds for tissue engineering. Expert Rev Med Devices. 2006;3:835-51.

106. Peltola SM, Melchels FPW, Grijpma DW, Kellomäki M. A review of rapid prototyping techniques for tissue engineering purposes. Ann Med. 2008;40:268-80. 